\title{
Modernization and Gender: a history of girls' technical education in Turkey since 1927
}

\section{Sule Toktas \& Dilek Cindoglu}

To cite this article: Sule Toktas \& Dilek Cindoglu (2006) Modernization and Gender: a history of girls' technical education in Turkey since 1927, Women's History Review, 15:5, 737-749, DOI: 10.1080/09612020600938707

To link to this article: https://doi.org/10.1080/09612020600938707

曲 Published online: 30 Nov 2006.

Submit your article to this journal $\pi$

Џll Article views: 258

Citing articles: 7 View citing articles $₫$ 


\section{Modernization and Gender: a history of girls' technical education in Turkey since 1927}

\section{Sule Toktas and Dilek Cindoglu}

This article is a historical analysis of Girls' Institutes in Turkey. These schools were established in the early Republican era in order to educate girl students to gender roles compatible with modernization and with the westernization project of the Turkish state. The analysis is based upon qualitative data (including interviews and focus groups). The findings point to four trends in the history of Girls' Institutes and in the characteristics and lifechances of graduates in the period 1927-70. These were (a) the shift from 'good housewife and mother' training schools to vocational schools; (b) the downgrading of the employment of graduates; (c) a shift from singleness to marriage; and (d) the redefinition of gender roles by women themselves.

\section{Introduction}

Education is one of the most important social institutions in modern societies, which provides training and skilled labour on the one hand, and reproduces existing cultural norms and values on the other. Historically, modern industries required a skilled and trained labour force. Both academic and vocational education, in return, have been shaped and transformed to serve modern industries and human resource development.

\footnotetext{
Sule Toktas is Assistant Professor in the Department of International Relations of Isik University, Istanbul, Turkey. Her research interests include women's studies, international migration, Turkey's non-Muslim minorities and Turkish politics. Her recent article on women officers in the Turkish Armed Forces appeared in Oriento Moderno. Correspondence to: Sule Toktas, Assistant Professor, Isik University, Faculty of Economics and Administrative Sciences, Department of International Relations, Kumbaba Mevki, Sile, 34980, Istanbul, Turkey. Email: sule@isikun.edu.tr

Dilek Cindoglu received her PhD from the State University of New York at Buffalo, USA. She is currently Assistant Professor and Assistant Chairperson at the Department of Political Science, Bilkent Univesity. She is a sociologist working on gender and work, power, health and sexuality issues in contemporary Turkey and Middle East. Email: cindoglu@bilkent.edu.tr
} 
Indeed, there is an assumption that there is a close connection between vocational education and economic growth and technological efficiency. ${ }^{1}$ In most cases, the state and private sector have cooperated to design appropriate education for the masses. ${ }^{2}$

With the rise of industrialization as a macro-economic trend, the tasks of men and women in the household were differentiated. The gendered division of labour demanded men to be breadwinners and women to be dependent homemakers. Education was invested in as a tool to prepare men for the labour force. Women's education, on the other hand, has tended to reinforce traditional gender roles regardless of the topic of their studies. Current studies show that even when women are trained for jobs, they are trained for low-status and low-paid positions, with little or no control over the work process (this is called occupational gendering and re-gendering). ${ }^{3}$ The literature on women's vocational education and training has identified these trends and countertrends in relation to globalization and the rise of the women's movement. ${ }^{4}$

However, in cases where industrialization and economic development are mostly initiated and controlled by the state, the gendered nature of education needs to be investigated further, partly because in these societies political ideologies have overshadowed economic developmentalism. In the case of Turkey both academic and vocational schools were the major mediums of Kemalist ideology. The primary function of these schools was not necessarily to provide a labour force for industry; rather, they were the carriers of the newly established, rising Republican ideology.

After the establishment of the Turkish Republic in 1923, the Turkish state initiated certain legal, educational and social reforms that targeted rapid modernization and urbanization. The aim of the newly founded state was the construction of a modern society in line with western lifestyles. In the implementation of modernization policies, Turkish women were expected to take on an instrumental role. The reforms, referred to as Kemalist or Republican reforms, signalled the new positioning of the state vis-à-vis women. ${ }^{5}$ Kemalism is a world-view commonly attributed to the Mustafa Kemal Atatürk's reforms to build the modern Turkish state. Women as homemakers and as mothers, who would raise the future generations of citizens according to the ideals of the state, were to disseminate the values of the Republic and construct the modern family. Republican gender ideology in general expected women to follow a particular form of education and act as visible ambassadors to challenge the backward image of Muslim women in the world as well as in Turkey. ${ }^{6}$ These new roles were not meant to confine women to the domestic sphere; in addition to their roles in the household, women were to take part in the public sphere by way of education and work. The visibility of women in politics was also an important concern for the Republican project of modernization witnessed by voting rights, which were granted to women first in municipal elections in 1930 and then in general elections in 1934. However, within Turkish society of the 1920s and 1930s, there were cultural values that associated women's roles primarily with the domestic sphere and which did not tolerate women's participation in the public sphere. ${ }^{7}$ These values were more prominent among non-elite families and were reflected in the area of education. Among the elite, where these values were overridden by new Republican ideals, women, in significant numbers, were able to receive secondary and tertiary education. Thus, when 
compared to 'developed' countries in the West, women's participation in higher education was significantly higher in the Turkish Republic. ${ }^{8}$ However, since these values were not equally internalized across all social groups, women's education beyond elite circles remained very limited. ${ }^{9}$ This was the case with respect to the secondary education of girls in Turkey in the 1930s when Girls' Institutes (later called Vocational High Schools) were first established.

Although similar types of schools were established in the late nineteenth century to train orphan girls to obtain a dowry before marriage or to prepare military uniforms for the army, the first Girls' Institute, in the instrumental and functional sense, was launched in 1927 in the capital, Ankara. By the end of 1927, there were two Girls' Institutes with a total of 456 students. In 1937, the number of Girls' Institutes reached 26 with a total of 9197 students enrolled at these schools; in 1947, there were 43 Girls' Institutes with 27,398 students; and in 1959, there were 98 Girls' Institutes with 54,337 students. ${ }^{10}$ Throughout this period, several other types of vocational schools had been established for female students at junior and high school levels. According to the data collected from the State Institute of Statistics, the total number of vocational and technical schools (at both junior and high school levels) including the Girls' Institutes was 503 in 1960 and 913 in 1970. In this ten-year period, the total number of female students educated in these schools was 112,519 . This figure correlated to $32.1 \%$ of all female students at technical and non-technical schools including religious and health schools. In comparison, the female students in normal (academic) junior high schools and high schools numbered 397,312 and composed $53.49 \%$ of all female students. ${ }^{11}$

The Girls' Institutes were single-sex educational schools at the high school level where daily contact with the opposite sex was curtailed. The curriculum included subjects such as sewing, embroidery, child development, pastry baking, and home economics. Thus the educational programme, which gave precedence to traditional gender roles in the private sphere, did not threaten the values of non-elite families. In this respect, the establishment of the Girls' Institutes emerged as a policy of compromise between the state and society: that is, girl children were to be educated, but along the lines of their gender roles and not in a co-educational environment. With the Girls' Institutes, the state would ensure women's education and women would spread a modern lifestyle throughout society. This seems to be verified by Village Women Mobile Education Courses established first in 1938, in which the graduates of the Girls' Institutes would teach village women the modern feminine knowledge required in a 'good housewife and mother'.

In order to trace the history of Girls' Institutes from the perspectives of women themselves, three focus groups and 14 life-history interviews were conducted, involving a total of 32 women recruited through the snowball technique. ${ }^{12}$ Participants graduated from various provincial Girls' Institutes in Turkey between the years 1960 and 1970 and were working as teachers in various Girls' Vocational High Schools in Ankara or as academics in the Faculty of Vocational Education at Gazi University in Ankara. A total of 18 women participated in three focus groups. For the life histories, 14 women were interviewed. Of the 32 women who participated overall, 5 were single, 2 were married without children, and 25 were both married and had children. By occupation, 
13 of the women were academic women and 19 were women teachers. All teachers and academics are also graduates of the Girls' Vocational Teacher Training College in Ankara, the only route for graduates of Girls' Institutes to become teachers. This involved a four-year university-level course with the objective of training students to become teachers at Girls' Institutes. When the Higher Education Council that brought all universities under a unified schema was established in 1982, the Girls' Vocational Teacher Training College turned into a faculty and became Gazi University Faculty of Vocational Education. The women who were then assistants in the Girls' Vocational Teacher Training College became professors (without the academic title 'Dr') after achieving the degree of proficiency in arts. However, some of them completed doctoral study either in social sciences or educational sciences, which is reflected in the title of 'Prof Dr'. ${ }^{13}$

The interviews and focus groups revealed four historical trends in women's vocational education in modern Turkey in the context of the Girls' Institutes: (a) the change from the 'good housewife and mother' training schools to vocational schools as evidenced in the curriculum change of the Girls' Institutes; (b) a change in career path for graduates, from ambassadors to medium or low rank state officials to qualified textile workers (this reflects the gradual downgrading of the employment of graduates, with a majority of housewife graduates and some teacher graduates being present throughout $)^{14}$; (c) a reduction in the number of graduates preferring to be single and an absolute increase in graduates preferring marriage and motherhood; (d) a shift from the definition of gender roles from 'above' through the prescription of state policies towards the redefinition and interpretation of gender roles by women themselves.

\section{From 'Good Housewife and Mother' Training Schools to Vocational Schools}

The aim of the Girls' Institutes when they were first founded in 1927 was to train future housewives and mothers who would adopt a modern lifestyle with an emphasis on diet, housing, behaviour, clothing and values. The goal was to introduce a new lifestyle that would spread into wider society. Sewing, embroidery, painting, child development, family economics, and nutrition were subjects of study. The Girls' Institutes were first established in the capital, Ankara, followed by other large cities such as Istanbul, Izmir and Bursa, and subsequently in smaller cities and towns. Over time, the school structure changed to emphasize vocational education in line with employment priorities. The 1950s and 60s witnessed immense industrialization, with a growing need for labour at the factories and workshops founded in urban areas. Industrialization, therefore, accompanied urbanization and impelled internal migration from rural to urban areas.

In 1974 Girls' Institutes were changed to Girls' Vocational High Schools due to new employment opportunities in different industrial sectors. The educational programmes of girls' vocational schools changed as well. New fields of specialization and school types were established. Today, the courses studied at Girls' Vocational High Schools include textile painting, textile weaving, sewing, pastry cooking, food control and analysis, electronics, jewellery making, hair dressing, etc. The reason for this change seems to lie in industrialization and the incompatibility of the former education 
programme with labour markets. The change in aim of education also reflects the change in expectations of women: from housewives and mothers to a dual role that combined an identity as worker with that of housewife/mother. ${ }^{15}$

The five-year National Development Plans for girls' vocational education that started in the 1960s envisioned such a change in orientation. ${ }^{16}$ For example, in the First Five-Year Development Plan (1963-67), it was stated that 'Girls' vocational education has to develop women's housewife skills and prepare them for vocations appropriate to their nature'. However, in the Second Five-Year Development Plan (1968-72), the aim for girls' vocational education was 'to prepare educational programs according to the demands of the economy'. In the Third (1973-77) and Fourth (1979-83) Five-Year Development Plans, the need for new specializations in various girls' vocational schools was emphasized, reflecting the effects of urbanization. In the Fifth Five-Year Development Plan (1985-89), it was stated that 'Girls' vocational education has to train the labour force needed for the sectors of agriculture, industry and services'. ${ }^{17}$ The objectives of the National Development Plans were also apparent in the interviews with the 1960-70 graduates of the Girls' Institutes:

The daughters of reputable families used to go there. The children of the rich were going to the Institutes because it was costly. These few families were sending their daughters. Our family was one of them in that area. Our schools were very special. There was the impression that 'She is going to the Institute so she knows how to dress, behave and talk; she will be a good family woman; she will be a good housekeeper. I mean if she does not earn her bread, at least she can sew at home and contribute to the family budget.' As I said, only a few families were sending their daughters to the Girls' Institutes because in addition to the courses of normal high schools, there were courses like home economics, cooking, courtesy, knitting, etc. in which good family housekeeping was taught. I mean these aspects were attractive in society. (Life history interview)

With the founding of the Republic, girls' education was made possible. And, at that time, the aim was to raise the ideal mother, the ideal housewife with certain capabilities in doing handicrafts. The education of women was an important matter because when mothers were cultured, the children would grow up better. Due to these considerations, this type of school was popular. In addition, the families [of the students] were certainly wealthy. Families of a certain origin, certain nobility, sent their daughters to this type of school. When [other] girls realized this, when families realized it, all of them put their effort into raising their daughters similarly. By looking at the families who were of a certain level, other families, despite their limited situations, joined in the unique group, the elite group. (Life history interview)

In those years the best families sent their daughters to the Institutes. The aim of our schools was to train both a good housewife and someone who has a vocation. Plus, [there was] the aim that when she becomes a housewife, she provides all the needs of the house, all the needs of the children and the husband. (Focus group)

Although the objective of the Girls' Institutes was to train good housewives and mothers, these schools oriented themselves more to the needs of industry and included specific courses addressing industrial sectors in the curriculum. This change is reflected in the interviews and focus group discussions. The profile of students had also changed. As families with high socio-economic status started to send their daughters to academic 
schools instead of vocational schools, the popularity of the Girls' Institutes diminished. In a similar fashion, the employment opportunities of graduates in the public sector, which has been considered prestigious because they provided guaranteed work and security, were limited. In this regard, the change from 'good housewife and mother' training schools to vocational schools accompanied the downgrading of graduate employment.

\section{Downgrading of the Employment of the Graduates}

The early graduates of the Institutes were recruited for relatively high-status administrative positions such as ambassadors in embassies, councillors, and general directors. As the number of Girls' Institutes increased and became established in cities and towns other than Istanbul and Ankara, employment opportunities for their graduates became more limited and less prominent. The characteristics of the families that sent their daughters to the Girls' Institutes changed as well. Over time, the popularity of Girls' Institutes lost ground among elite families, and non-elite families started sending their daughters to these schools. In the interviews, women mentioned that after the 1970s, the daughters of families with low socio-economic status attended Girls' Vocational High Schools. According to Feride Acar, this decrease in the popularity of Girls' Vocational Schools was not only due to the gradual loss of their mission to westernize women. It was also a result of increasing industrialization that required different labour skills from women workers. ${ }^{18}$

Similarly, in the 1930s and 1940s, when the Institutes were more popular among elite families in Istanbul and Ankara, their graduates were often recruited to high official administrative positions. However, by the 1960s, middle and lower middle-class graduates tended to be employed in clerical positions in state-administered post offices and banks. Teaching careers in Girls' Institutes, nonetheless, remained as a good opportunity for graduates of the Institutes who completed further education. Women teachers benefited from short working hours and long summer vacations in addition to the universal high pension system in the public sector. Therefore, teaching careers well suited women's dual roles at home and work. In the interviews, women mentioned the employment opportunities of 1960s graduates as follows:

At those times, it was very easy to find jobs in state offices and none of the [graduates] became housewives. Every one of them started working in a state office. The aim was not exclusively to train housewives. In fact it started like that but the result did not turn out to be so. Everybody could find a job in a state office and could start working after finishing school. (Life history interview)

Among our friends, only I became a teacher. Others started working in banks. Two of them took high school examinations externally and became pharmacists. Some of them started working as state officials, I mean, generally all of them worked. Of course there were some who became housewives. It is true that the Institutes train good housewives but for the ones who carry on with the higher education, they train good working women. I was able to enter the Teacher Training College so why should I be a housewife and sit at home? Am I wrong? (Life history interview) 
Yes, of course, they all found jobs and worked. Possibly the aim was not that but maybe due to life's economic conditions. That maybe, I mean, that is the main cause, I mean, the economic condition. Now, when I think about my school friends, they all wanted to work. The ones who could not attend the Teacher Training College found irrelevant jobs. For example, one of my friends became a policeman. One of them started working in a bank. Another worked in the private sector. But all of them had the aim of getting education, I mean, in the Teacher Training College. (Life history interview)

Graduates of the 1970s and 1980s had completely different characteristics; they were the daughters of families in peripheral districts of cities and towns and of lower socioeconomic status. Today, as their educational programme suggests, the students of Girls' Vocational High Schools can be employed in different industrial sectors.

\section{The Path from Singleness to Marriage}

The number of graduates of Girls' Institutes choosing to remain single was significant in the early 1930s but over time, especially after the 1970s, this tendency decreased. Although there is no statistical information available, the oral histories conducted with the women in this study point to the existence of such a trend. The first graduates of the Girls' Institutes were viewed as women of the Republic, women of mission and ideal. They acted as role models for a whole society. They worked devotedly for the dissemination of Republican reforms in the public sphere as teachers, high state officials, and civil servants. They advocated good motherhood for other women in society but they never became mothers themselves. However, gradually, women graduates ceased to remain single and chose to marry and have children, particularly after the 1970s. This situation has close ties with the availability of work opportunities and the status of positions. The extracts below point to the significance of remaining single among the graduates:

I mean the people who taught us... trained us not only as housewives and mothers. We would be in certain cadres in the future. Our education staff was really a perfect one. Because when the Girls' Institutes were opened in 1930s with Atatürk's own initiation, our teachers were already the women of the Republic, I mean, the ones who were giving us the education were the women of the Republic... I think it is due to this staff. In addition, I believe that the Republic had a wide influence. I mean the generation after the Republic, I mean that generation raised in times of the Republic had a wide influence on that generation of the '60s. (Life history interview)

In a specific period, really, they were the people who did not ever marry. For example, our school principals at school, our branch teachers. But the next generation, the generation after, considered marriage [to be] important... But really, the ones who remained single were the majority among the graduates of the Girls' Vocational Teacher Training College. I interpret this as their considering themselves superior by giving priority to work life above everything. (Life history interview)

The ones who were single were many. It is true. But that's the way it was... In this, our schools had great role. Why do I say this? First of all, the children of a very different stratum of the society attended these schools. The wealthy families wanted wealthy environments. Girls wanted a husband who could give them what their parents gave them. There was that expectation. (Life history interview) 
The availability of work opportunities decreased in the 'prestigious' and 'life guaranteeing' public sector and increased in the private sector, especially in relation to lowskilled work in the industrial sectors. As the status of work roles diminished due to lack of work guarantee/security, the proportion of graduates of the Girls' Institutes who remained single decreased. Such a change in the graduates' profile also pointed to the erosion of the image of the 'woman of the Republic': the woman who devoted herself to the state ideals of 'advancement to the levels of western civilizations'.

\section{The Definition of Gender Roles}

In line with the objectives of the newly founded Republic, which adopted new definitions of 'modern' and 'pre-modern' lifestyles and opted for the former, the Girls' Institutes participated in the modernization of women's roles within the family. However, the women in our research seem not to have taken what was pre-modern and what was modern for granted but, rather, developed their own conceptualizations and redefinitions of each over time. Although state definitions of modern gender roles were reflected in the curriculum of the Girls' Institutes, women actively participated in the construction of their own roles and identities. In interview data, the pre-modern stood for the confinement of women within the domestic sphere and in this sense, women were very loyal to the Kemalist world-view. However, contrary to official ideology, the pre-modern was also associated with the actual oppression of women. To illustrate, within the interviews, women doing all the housework was viewed as pre-modern, and the sharing of housework by both the husband and the wife was viewed as modern. Women doing what the husband ordered them to do was viewed as pre-modern, but sharing decisions on family matters was modern. The dependence of women on their husbands was pre-modern, but the independence of women was modern. Women, in this regard, seem to have been involved in constant negotiation with the state. Women's definition of what their gender roles should be is illustrated as follows:

This desire [to work] is due to the value given to women: the independence of women, to gain economic independence, to achieve self-actualization. This is not only an effect of families but also the newly flourishing values in the society... the girls started to adopt those values of the society. Role models started to spring up... Why can't she be one of them? She may be motivated to overcome all the difficulties. (Life history interview)

In our school, we used to offer evening courses to adults. Ladies attended no matter if they were working or not. In these courses, we taught ladies who have received only primary education. Since I suffered from my husband a lot, I always tell themespecially the ones who were newly married-'You will get married someday. If you have a son, give him housework to do. What can he do? He can at least make his bed. $\mathrm{He}$ can put the garbage out. He can do some ironing. Please, make him do these things.' I repeated this in every class. My mother-in-law did not make her son do these tasks. I wish she had taught these tasks to my husband. Nowadays, both men and women should work to make ends meet. If a man knows how to do housework, he can become happier and in turn make his family happier. There would be fewer problems. (Focus group) 


\section{The 1960-1970 Alumni Profile: women of the 'inner' periphery}

The graduates of the 1960s form a different profile than other graduates of the Girls' Institutes. The graduates of the 1930s and 1940s were mainly from upper and middle class families who were living in the central districts of Ankara and Istanbul. Their parents had a secular education and high levels of income. They were strictly loyal to Republican values and ideals. However, the women who graduated from the Girls' Institutes after the 1970s had lower-middle-class backgrounds. Their families were inhabitants of newly urbanizing provinces or towns, had lower class links and lower education levels. The 1970s was the decade when Kemalist ideological hegemony started to lose its roots, especially under the influence of a polarized ideological spectrum and cosmopolitan sociocultural conjectures. At the same time, the 1960s and 1970s were transitory years when 'the Republican woman' stereotype started to be replaced by the 'qualified worker'.

In the early years of modern Turkey, the intellectuals, military officers, and state officials, all of whom comprised the state elite, internalized the values of the Republic, and, furthermore, actively contributed to the diffusion of these ideals to other groups in society. In this sense, they were a Republican elite or centre. ${ }^{19}$ This elite had close ties with local notables who were to spread Republican ideals to the periphery, comprised of low socio-economic status families living in mostly rural settlements or newly urbanizing towns. The families of the women who graduated from the Girls' Institutes between 1960 and 1970 were from the periphery. They were mainly families who belonged to what can be defined as local middle classes (i.e. fathers were middle and lower level civil servants, local artisans, shopkeepers and merchants). Since social change for modernization spread from the top down to the lower strata of the society and from more urban settlements to rural ones, ${ }^{20}$ these families living in newly growing cities could be considered the 'inner' periphery. They comprised the middle and lower middle classes of urbanizing towns. They were not the families of shanty towns that emerged due to migration from villages to cities after the 1970s; neither were they the high notables, the very respected, rich families of the provinces. They were the middle socio-economic status families and as the 'inner' periphery of the centre, newly adapting Republican reforms. The fathers of these women seemed to be loyal to the Republic, yet not as much as those in the centre. The readiness of civil servants for social change can be understood with respect to their positions in the hierarchical state administration. However, the loyalty of tradesmen to Republican ideals verifies the immediate success of the state's attempt to build up a modern society. Interviews suggest that the families of the women, as members of the 'inner' periphery, seemed to internalize social change. As one of the women said in the life history interview:

My father used to say that girls needed education for the development of Turkey. I mean for [daughters] to be good mothers, cultured mothers by learning child care, cooking, I don't know, for them to be more active, more social, my father used to say, from time to time, that Girls' Institutes were very vital. Although my father did not have any education, he was a very active, very social person. In the past, nobody knew things like sewing. Only the wives of a couple of state officials or a couple of military officers would come and teach the local people how to sew so that they would learn. 
This is why my father established the Girls' Institute in Kars [an eastern province of Turkey], I mean, he was the sponsor. (Life history interview)

The families of the women supported their daughters' education at the Girls' Institutes and their work after graduation. ${ }^{21}$ Families wanted a vocational education for their daughters to secure a life for them that did not depend on other people, especially on men (brothers or husbands) in later life. Vocational education was thought to provide the potential for self-sufficiency, in other words, the ability to 'stand on one's own two feet'. ${ }^{22}$ One of the interviewees described this value as follows:

Since my parents had only a primary education, they wanted to fulfil their own lack by our education. They supported us to attain a vocation. Another thing, there was also the thought that for being a girl child, she has to get a vocation. I mean, there was no son in the family. My father was not healthy. For that reason, they thought I needed to get vocational education. They said, 'you may encounter many circumstances in life; you may not have a good marriage and may not stay married. You need to have a vocation.' (Life history interview)

The Girls' Institutes of the 1960s-70s informally required a certain financial capacity from girls' families for the costly materials required for applied education in workshops. Although higher education opportunities after graduating from the Girls' Institutes were limited, it was thought that the girl children would at least be taught how to sew or to do handicrafts, by which women could guarantee themselves some means of support.

Another factor that shaped family choice of an Institute was that Institute graduates were licensed as 'good housewives and mothers'; graduates with this official endorsement were preferable to families with high socio-economic status as mates for their sons. Therefore, families could ensure a good marriage for their daughters and, furthermore, security in marriage whether they were working or not. In this regard, the preference of the women's families for Girls' Institutes reveals an additional appeal: the tool for social mobility as indicated in the following extract:

Furthermore, the graduates of the Girls' Institutes made very good marriages. Even the ones who could not attend the Girls' Teacher Training College after they graduated from the Girls' Institutes made very good marriages, some of them with doctors and some of them with engineers. None of them married only a high school graduate. (Life history interview)

In the 1960s, non-technical academic high schools were more respected amongst high socio-economic status families; however, among the families who had middle socioeconomic status and who were living in newly urbanizing cities composing the 'inner' periphery, the Girls' Institutes were more popular. The reasons for this difference in popularity can be traced back to Republican ideals and the levels and degrees of their internalization by different societal groups. The Girls' Institutes, when established in the early Republican times, were more popular among high socio-economic status families due to their instrumental role in providing girls with both 'educated' and 'potentially good housewife and mother' titles. Education for both men and women was strictly required by the state by ways of educational campaigns and some sanctions. 
The need for women's domestic work was emphasized ideologically. If women did not work, they would contribute to the formation of the nation state and its ideals of modernization through their mothering and housekeeping roles. Mothering was important because women were the dominant figures in nuclear families; mothers would raise citizens for the state according to the priorities of the Republic. Housekeeping was important to establish the modernized lifestyle. Women's education was seen as proof of loyalty to the goals of the new regime. As Girls' Institutes were established in many cities, the wider diffusion of education and its availability to women led nonelite women to the public sphere. The interviewees explained their perceptions of the popularity of the Girls' Institutes before 1970s as follows:

Yes, in that time, students from elite families were recruited to the school that I was going to. In general, they were from families who had better economic conditions. (Life history interview)

At that time, the daughters of good families were going to the Institutes. The one who did not have a good economic condition could not attend because it was costly [to purchase the materials for the courses such as sewing]. (Focus group)

This reflects recruitment patterns for professional and civil-service positions as well. ${ }^{23}$ The state first employed men of the elite and then its women, rather than men of lower socio-economic groups. Thus, an important proportion of professionals in Turkey were women in the 1930s and 1940s. ${ }^{24}$ This general tendency no doubt also constituted one of the bases for some graduates of the Girls' Institutes to be appointed to high-level positions such as ambassadors, counsellors and high state officials in different departments. When employment opportunities became more limited and the upward mobility of men of lower socio-economic status groups increased, more families of high and middle socio-economic status started to direct their daughters to university education through which women could routinely secure high-status professions. ${ }^{25}$ However, university education required a non-technical high school diploma. The popularity of the Girls' Institutes declined over time. The demand for them decreased but at the same time the demand for academic high schools whose graduates had greater access to university education increased. In the 1960s, the remaining job opportunities for Institute graduates were mainly clerical positions in post offices, banks and schools.

\section{Conclusion}

Turkish women's schooling and employment has roots in the Ottoman period, although women's formal participation in education and employment started mainly in the late nineteenth century. However, the content of education has changed over time. Indeed, in this article we have argued that in the specific case of the Girls' Institutes this change has been tremendous. Originally the education project was a part of the Kemalist Republican Project to enlighten and westernize the masses. It was designed to serve a particular type of modernization. Starting from the nineteenth century, Turkish women had access to education, yet educational opportunities were enjoyed by very small numbers of women who were from upper-class families living in 
Istanbul. Women had also worked during the Balkan Wars (1911-12) and World War I due to the great loss of male labour. However, with the introduction of educational reforms by the new Turkish Republic, modern, unified, secular and co-educational institutions were established in order to spread education to the masses. The Girls' Institutes emerged as a policy of compromise between the state and wider society and received support from the masses. In a sense, the state's search for compromise serves to counter accusations regarding the Jacobin nature of the Kemalist state.

Over time, various changes have taken place in the lives of Turkish women. This study of the Girls' Institutes has illuminated the relationship between society and the state on the macro level. First, there was a shift in the content of education. The focus on producing 'good housewives and mothers' was replaced with an emphasis on a skilled labour force. Second, there was a clear and gradual decline in the status of the jobs that women were appointed to do. Earlier graduates were ambassadors and councillors, whereas the graduates of later years were post office workers, and most recently, textile workers. Third, the first graduates predominantly preferred to stay single but, among recent graduates, being single is a very rare phenomenon. Fourth and finally, these women redefined traditional gender roles and transformed them into more egalitarian frameworks.

\section{Notes}

[1] C. S. Ihm (1996) The Dynamics of Implementing Vet Reform and Lifelong Learning in Korea, Journal of Education and Work, 12(3), pp. 309-321.

[2] C. Mayer (2001) Transfer of Concepts and Practices of Vocational Education and Training from the Centre to the Peripheries: the case of Germany, Journal of Education and Work, 14(2), pp. 189-208.

[3] J. Brine (1992) The European Social Fund and the Vocational Training of Unemployed Women: questions of gendering and re-gendering, Gender and Education, 4(1/2), pp. 373-395.

[4] E. Butler \& F. Ferrier (2000) 'Don't Be Too Polite Girls!' Women, Work, and Vocational Education and Training: a critical review of the literature (Leabrook: National Center for Vocational Education Research).

[5] A. Durakbaşa (2000) Halide Edib: Türk modernleşmesi ve feminism [Halide Edib: Turkish modernization and feminism] (Istanbul: İletişim Yayınları).

[6] D. Kandiyoti (1989) Women and the Turkish State: political actors or symbolic pawns?, in N. Yuval-Davis \& F. Anthias (Eds) Women-Nation-State (London: Macmillan).

[7] A. Kadıoglu (1994) Women's Subordination in Turkey: is Islam really the villain?, Middle East Journal, 48(4), pp. 645-660.

[8] F. Acar (1994) Higher Education in Turkey: a gold bracelet for women, in S. Lie, L. Malik \& D. Harris (Eds) The Gender Gap in Higher Education (London: Kogan Page).

[9] N. Abadan-Unat (1991) The Impact of Legal and Educational Reforms on Turkish Women, in N. R. Keddie \& B. Baron (Eds) Women in Middle Eastern History: boundaries in sex and gender (London: Yale University Press).

[10] Turkish Ministry of National Education General Directorate of Girls' Technical Education (1996) 1865-1996: 131 yıl (Ankara).

[11] The figures on schooling and female students are compiled from Turkish State Institute of Statistics (1995) Women in Statistics No: 1712 (Ankara: State Institute of Statistics); and Turkish State Institute of Statistics (1996) Statistical Indicators 1923-1995 No: 1883 (Ankara: State Institute of Statistics). 
[12] The research was a partial fulfilment of M.Sc. degree of Sule Toktas in Middle Eastern Technical University, Gender and Women's Studies Program.

[13] According to the information of the Assistant Dean of the Gazi University Faculty of Vocational Education: the total number of the faculty members was 133 at the time of the interviews; 99 of the total 133 faculty members were graduates of either Girls' Institutes or Girls' Vocational High Schools (Girls' Institutes were changed to Girls' Vocational High Schools in 1974); 55 of these 99 women were graduates of Girls' Institutes in the period of 1960-70; and the number of married women was 43 and unmarried women was 12 .

[14] The figures related to career paths of the graduates are lacking. Therefore, the proportion of women who went on to be teachers after graduating from the Girls' Institutes is unknown.

[15] The competing demands of paid work and family commitments, as a global phenomenon, is regarded as the most central challenge in women's lives and has been widely discussed in studies on the dual roles of women. See, for example, M. A. Milkie \& P. Peltola (1999) Playing All the Roles: gender and the work-family balancing act, Journal of Marriage and the Family, 61(2), pp. 476-490; D. A. Skinner (1980) Dual-career Family Stress and Coping: a literature review, Family Relations, 29(4), pp. 473-481; and M. A. Claesson \& R. A. Brice (1989) Teacher/Mothers: effects of a dual role, American Educational Research Journal, 26, pp. 1-23.

[16] The parts of the five-year National Development Plans about girls' vocational education are summarized in Turkish Ministry of National Education General Directorate of Girls' Technical Education (1984) Kız teknik öğretim genel müdürlüğ̈̈ çalişmaları 1983-1984 (Ankara: Turkish Ministry of National Education General Directorate of Girls' Technical Education); and in Turkish Ministry of National Education General Directorate of Girls' Technical Education (1986) Kız teknik öğretim genel müdürlüğ̈̈ brifingi (Ankara: Turkish Ministry of National Education General Directorate of Girls' Technical Education).

[17] Turkish Ministry of National Education General Directorate of Girls' Technical Education (1992) Ikibinli yıllar öncesinde Türkiye 'de kadın eğitimi: Türkiye 'de kadın eğitimi birinci uluslararası konseyi (Ankara: Turkish Ministry of National Education General Directorate of Girls' Technical Education).

[18] F. Acar (1995) Women's Education in Turkey: a history of paradoxes, paper distributed as course material for The Women Question in Turkey: interdisciplinary conceptualizations (Ankara: Middle East Technical University).

[19] S. Mardin (1990) Türk siyasasını açıklayabilecek bir anahtar: merkez-çevre ilişkileri [A Key to Explain Turkish Polity: centre-periphery relations], in Şerif Mardin Türkiye 'de toplum ve siyaset makaleler I [Şerif Mardin Articles on Turkish Society and Politics I] (İstanbul: İletişim Yayınları).

[20] F. Özbay (1999) Gendered Space: a new look at Turkish modernisation, Gender and History, 11(3), pp. 555-569.

[21] F. Acar (1993) Women and University Education in Turkey, Higher Education in Europe, 18(4), pp. 65-77.

[22] Acar, 'Higher Education in Turkey'.

[23] Abadan-Unat, 'The Impact of Legal and Educational Reforms on Turkish Women'.

[24] A. Öncü (1979) Uzman mesleklerde Türk kadını [Turkish Women in Professions], in N. Abadan-Unat (Ed.) Türk toplumunda kadın [Woman in Turkish Society] (Ankara: Türk Sosyal Bilimler Derneği).

[25] Acar, 'Women and University Education in Turkey'. 